\title{
The Role of Self-assessment in Promoting Iranian EFL Learners' Motivation
}

\author{
Parviz Birjandi \\ Islamic Azad University, Science and Research Branch \\ Faculty of Foreign Languages, West Laleh, Janat Abad, Tehran, Iran \\ Tel: 98-211-4440-6048Ｅmail: pbirjand@yahoo.com \\ Nasrin Hadidi Tamjid \\ Islamic Azad University, Science and Research Branch \\ No.34, Koy-e-Khazar, Abresani Ave., Tabriz, Iran \\ Tel: 98-411-658-7672_E mail: nhadidi@iaut.ac.ir
}

\begin{abstract}
During the last decade, increasing attention has been paid to the role of learner in the process of language learning and testing. Moreover, there is a general consensus in the literature that motivation is one of the key learner characteristics. The objective of this study was to explore the role of journal writing as a self-assessment technique in promoting Iranian EFL learners' motivation. The participants were 60 intermediate students in two groups. The particular self-assessment technique used in the experimental group was journal writing. At the beginning and end of the semester, both groups took a language proficiency test to ensure their homogeneity, and completed a questionnaires regarding motivation. The results revealed that writing journals in a regular base had a role in promoting the learners' motivation.
\end{abstract}

Keywords: Self-assessment, Journal writing, Motivation

\section{Introduction}

It is generally acknowledged that in order to assess the students' performances we need to use a variety of assessment methods. Yet, in traditional classrooms, which are prevalent in Iran, the teacher is the only evaluator. Such evaluation is acceptable in case of tests whose items have one correct answer, but in performance tests, such as writing compositions, the evaluation is not so straight forward. In order to compensate for the limitations of teacher- assessment, alternative assessment including self- assessment has been the focus of attention. In this modern view towards assessment, learners are trained to assess their own learning progress, and can identify their own strengths and weaknesses. On the other hand, motivation is considered as a key feature in the success of language learning. In fact, as Dornyei (2000) puts it "motivation provides the primary impetus to embark upon learning, and later the driving force to sustain the long and often tedious learning process" (p.425). With regard to both self-assessment and motivation, McMillan and Hearn (2008), in their paper entitled "Student self-assessment: The key to stronger student motivation and higher achievement" maintain that " Student self-assessment stands alone in its promise of improved student motivation, engagement, and learning” (p. 40). Thus, we begin with a detailed definition of self- assessment, motivation, and journal writing, and then review the research that supports the positive impact of student self-assessment in the classroom. The intent of the present study is to see if self-assessment can have a significant role in promoting Iranian EFL language learners' motivation in writing classes.

\section{Review of the related literature}

\subsection{Self-assessment}

The term 'assessment' comes from 'ad sedere' - to sit down beside. According to Wang and Wang (2007), the implication of its etymology is that assessment is primarily concerned with offering the learner guidance and feedback. Matsuno (2009) maintains that in L1 assessment, self-assessment is considered as an effective tool which helps students to understand the purpose of the assignment and the assessment criteria (Orsmond et al., 1997), and to improve learning (Sullivan \& Hall, 1997), which softens the blow of a bad grade by helping students understand the reasons for their grade (Taras, 2001).According to Nunan (1999), assessment, as a subcomponent of evaluation, refers to "the tools, techniques, and procedures for collecting and interpreting information about what learners can and cannot do"(p.85). In modern views to language teaching, there is an attempt to train learners systematically in ways of assessing their own learning progress. Kavaliauskiene (2004) argues that through self-assessment, learners get an opportunity to think about their own progress and find ways 
to change, adapt or improve it. In fact, most language learners, specially the successful ones, regularly engage in self-assessment in the process of their learning.

\subsection{Motivation}

Various definitions of motivation have been suggested over the decades. Dornyei (2009) maintains that motivation is one of the most important concepts in psychology and language education, which is commonly used to explain learners' success and failure in learning. It is argued that neither remarkable abilities nor good teaching are sufficient to guarantee learners' achievement. Dornyei (2000), considering motivation as a key learner characteristic in determining the rate and the success of language learning, argues that there is a general consensus that motivation has both a qualitative and a quantitative dimension. According to Dornyei, "the former concerns the goal or the direction of learning, and the latter the intensity of the effort invested" (p.425). Regarding motivation Dornyie ( 2000) argues that motivation in L2 is a highly eclectic and multifaceted construct which consists of different motives related to certain features of the L2 (e.g. attitude towards the L2), the language learner (e.g. self- confidence), and the learning situation .

One way to conceptualize motivation, which has direct implications to educational settings, has been proposed by Deci and Ryan (1985). Deci and Ryan in their self- determination theory argue that different subtypes of motivation, i.e., intrinsic and extrinsic motivation, can be shown along a continuum depending on the degree of self- determination (Pae, 2008). Pae (2008) notes that "intrinsically motivated people are engaged in activities because of the inherent pleasure and satisfaction derived from doing so, rather than contingencies or reinforcements external to the activities" (p.7). In other words, intrinsic motivation refers to motivation to engage in an activity because, as Noels et al. (2000) put it, the activity is enjoyable and satisfying to do.

\subsection{Rationale for self-assessment}

The motives for introducing self- assessment vary and usually include the practical impossibility for teachers to keep effective track of all their students' changing learning needs (Kavaliauskiene, 2004). Oscarsson (1989) gives six rationales for self-assessment procedures. First, he stresses that self-assessment promotes learning. It gives learners training in evaluation which has beneficial consequences for language learning. Secondly, it raises the awareness of both students and teachers of perceived levels of abilities. Through self-assessment, learners are encouraged to look at course content more carefully, and develop evaluative attitudes toward what and how they learn. Thirdly, self-assessment is highly motivating with regard to goal-orientation. Learners gain knowledge of learning goals through reflection. Fourth, the involvement of learners in the assessment process results in the learner's broader perspective within the area of assessment. Fifth, by practicing self-assessment, students take part in their own evaluation, sharing the burden of assessment with their teacher. Finally, self-assessment may have long-term benefits, as one of the main aspects of autonomous language learning is the ability to assess the progress which is made.

Brown (2004) maintains that the theoretical justification for self-assessment comes from a number of wellestablished principles of second language acquisition. One of these principles is the principle of autonomy, which according to Brown, is one of the basis of successful learning. Brown notes that developing intrinsic motivation seems to have major importance in successful acquisition of any set of skills, and the learners' self-involvement increases such motivation. Liang (2006) also in summarizing the benefits of self-assessment notes that self- assessment through increasing learners' knowledge of their learning goals and their learning needs, enhances their motivation and goal orientation.

Kavaliauskiene (2004) mentions further motives as including recognition of self- assessment as an essential component of successful learning beyond teaching institutions, and the aim to make students more responsible for their own learning, through developing reflective learning habits. In other words, self-assessment helps students monitor their own progress from their own work. Black and William (1998 cited in Kavaliauskiene, 2004) argue that one of the reasons to integrate self- assessment into language courses is that it increases motivation and goal orientation in learning.

The present study investigates the role of self-assessment on promoting the learners' motivation. The particular self-assessment technique used in this study is 'journal writing', which according to Genesee and Upshur (1996), can be used to collect information for evaluative purposes, including self- assessment.

\subsection{Journal writing}

There seems to be an increasing tendency toward using qualitative research methods in applied linguistics. This particular trend helps researchers gain a more holistic perspective on issues related to language learning. Allwright (1983) maintains that research on language learning can be carried out in two ways, through 
observation or introspection. Similarly, Marefat (2002) notes that in order to gain insights into language learning studies, and to get closer to learner needs, the researcher is required to guide the learners to examine their own behavior, i.e., introspection. Journal writing is in fact a means of introspection, or as Walker (2006) puts it, a pedagogic technique which promotes reflection. Porter et al. (1990, cited in Marefat, 2002) maintain that journals are used in writing courses "to exploit the writing - learning connection" (p. 104). One of the main aspects of L2 motivation is the learners' attitude towards language, and language learning. Marefat (2002) notes that writing journals during the course help learners' develop positive attitudes toward writing. In fact, journal writing helps language learners write without self-consciousness or inhibition, similar to natural writing (Schneider, 1994). Similarly, Sommer (1989, as cited in Kerka, 1996) argues that one reason for using journals in EFL classes is that they are a safe place to practice writing daily without the restrictions of form and evaluation.

On the other hand, post- process approaches to writing are closely associated with critical approaches to language education. Mirhosseini (2009) states that increasing concern with the social aspect of writing has led to the emergence of post- process approach in writing, which emphasizes understanding writing as part of literacy in its social context (Atkinson 2003; Hayland 2003; Truesdell 2008, cited in Mirhosseini, 2009). Within this perspective, writing can be "part of critical literacy practices that involve questioning received knowledge and immediate experience" (Perry, 1996, cited in Mirhosseini, 2009, p. 41). Mirhosseini argues that journal entries may integrate all aspects of product, process and post-process approaches to writing into a unified whole. Teachers read and respond to journal entries every week; they read journals primarily as letters not as their students' writings, write comments on the points students make, answer their questions, and ask questions, as it is the case in any meaningful dialogue. Mirhosseini further notes that, when it is needed, teachers can directly or indirectly draw learners' attention to formal linguistic aspects (as in a product-oriented approach), comment on the communicative aspects (as in a process approach), and critically focus on the social and personal content of students' writings (as in a post-process approach) ( Mirhosseini, 2009). According to Mirhosseini, through journal writing the students increase willingness to write, develop positive attitudes towards EFL learning, decrease anxiety, and promote self-confidence, which are particularly related to the present study. Moreover, Brown (2004) considers journal entries as a kind of strategic planning and self- monitoring can enhance intrinsic motivation.

\section{The present study}

\subsection{Methodology}

The main research question here is to find out if self-assessment can have any role in promoting learners' motivation. The specific self- assessment technique used here is journal writing.

\subsubsection{Participants}

The participants were 60 intermediate TEFL students studying at Islamic Azad University of Tabriz. There were two groups of students, 30 in the experimental group, and 30 in the control group. The students in the experimental and control groups were all exposed to the same content and instructional method, and they had the same instructor. There was only one difference, i.e., the students in the experimental group received self-assessment training. The particular self-assessment technique used in the experimental group was journal writing. In this study, journal writing refers to students' reactions to class events, materials, the instructor, as well as their own learning. The participants were taking Writing 2 course. These students have already taken Principles of writing and Writing 1 classes. In Writing 2 class, essay writing and a few types of expository essays, e.g., example essay, classification, and comparing and contrast, were introduced. Moreover, the participants were asked to write their journal entries on a weekly basis, for about 10 to 15 minutes at the end of each session. They were told not to worry about grammar or spelling and to focus on expressing their reflections on classroom activities and their personal concerns freely on paper. The teacher read and responded to journal entries every week.

\subsubsection{Instrumentation}

At the beginning of the semester, both the experimental and control groups took a language proficiency test to ensure their homogeneity. Then, the data were gathered through a motivation questionnaire, in Likert scale (see Appendix 1). The participants were told that it was just part of a research project. Moreover, an emphasis was made that there was no 'right' or 'wrong' answer. The questionnaire was administered twice, at the beginning and at the end of the term. The questions were written in English and the students were required to question any ambiguity in the items. The questionnaire took a participant 10 minutes to finish. The questions in the questionnaire were related to the participants' intrinsic motivation. 


\subsubsection{Procedure}

The experimental group, JW+TA group, did journal writing as a self- assessment technique. Every week, the learners in the experimental group were required to write journals, which included the reflections of the students on what they did in class, what they learned, what problems they had, and how they felt in the class since the affective state of the learner is important in self-understanding (Brown, 2004). Yet, it was important to give the students some guidelines regarding journal writing. The particular guideline used in the present study was adapted from Brown (2004). Thus, the students in the experimental group were provided with the following guidelines:

a) The students were introduced to the concept of journal writing. For almost all Iranian students who are from an educational system that overlooks the notion of teacher-student dialogue and collaboration, journal writing is difficult at first. With modeling, assurance, and purpose, the teacher tried try to help students become comfortable with the process.

b) The objectives of the journals were stated. In this study the main objective of the journals here was to provide the learners in the experimental group with the opportunity to reflect on their learning process, learning environment, on themselves as learners, as well as identify ways to plan, monitor, evaluate, and adapt to learning.

c) Some guidelines were given on what kinds of topics to include. In writing journals, at first, the instructor asked the students to answer "what questions", for instance, what the students have learned, and later, "how questions", e.g., how they can improve their learning.

d) The criterion for assessing journals was specified. Having clarified those journals would not be evaluated for grammatical correctness, the teacher stated how they would be evaluated. Effort as shown in the thoroughness of students' entries would be important. Also, the extent to which entries reflect the processing of course content and the learning process would be considered.

e) Optimal feedback would be provided in the responses. Based on McNamara's (1998, cited in Brown, 2004) classification of feedback, the teacher would provide the students with cheerleading feedback (i.e., celebrating students' successes or encouraging them to persevere through difficulties) and instructional feedback. Moreover, the students were provided neutral feedback. This means that the researcher would go over some problematic points in the journals with the class without mentioning the names of individual students.

f) Appropriate time frames and schedules were designated. Journals needed to be considered by students as integral parts of a course. The students were asked to fill in their journals during a spare ten minutes at the end of each writing class. All of the journals were collected by the teacher at the end of each session. The teacher gave comments on students' reflections. Moreover, the teacher spent a few minutes on a short class discussion about the journals the following session.

g) Some sample journal entries were reviewed. Finally, in order to make journal writing as clear as possible, the instructor read some selected parts of the journals students wrote in pervious terms, focusing on their strong and weak points.

\subsubsection{Developing the questionnaire}

In the first step of this study, a motivation questionnaire in Likert- type had to be developed. To develop the questionnaire, first the researcher conducted a review of the related literature, identifying different dimensions of motivation. For example, Deci and Ryan's (1985) Intrinsic Motivation Inventory (IMI) has six subscale scores measuring participants' interest/enjoyment, perceived competence, effort, value/usefulness, felt pressure and tension, and perceived choice while performing a given activity. According to Deci and Ryan, interest/enjoyment subscale is the only subscale that assesses intrinsic motivation, per se. In Guilloteaux and Dornyei's (2008) 20-item Student Motivational State Questionnaire, three aspects of motivation were considered: a) attitudes toward the course, b) linguistic self- confidence, and c) L2- classroom anxiety. It should be mentioned that it needs a long questionnaire to represent all dimensions of motivation in its total complexity. In the present study, from the reviewed questionnaires (e.g., Deci and Ryan 1985, Clement et al. 1994, Mori 2002, Guilloteaux and Dornyei 2008), the items related to the intrinsic motivation were mainly focused, as the purpose was to develop an intrinsic motivation questionnaire. Moreover, there was an attempt to adapt the questionnaire to items related to learning English in general and writing classes in particular. It should be mentioned that this questionnaire was designed to target the students' situation - specific motivational disposition related to their writing course. Consequently, the question did not include items seeking to tap into more general attitudinal or motivational factors, such as integrativeness. The included questions were mainly attitudinal. In order to check content 
validity, four of the researchers' colleagues who taught writing courses, were consulted. Moreover, the main study was preceded by a pilot study in which the questionnaire was tested on a sample of 30 ESL learners taught by the researcher in a writing class at Islamic Azad University, Tabriz Branch. The students represented a population similar to that of the main study sample but were not included in the main study. They filled in the first version of the motivation question, and based on the results the reliability of the questionnaire came out to be 0.84 . Table 1 illustrates the result.

The first version had 50 items. Moreover, the questionnaire was administrated to a similar population of 110 students, taking writing classes, to run factor analysis. The total cases for factor analysis included 60 in the main study, 30 in the pilot study, plus 110 cases who only completed the questionnaire. After running the factor analysis, those items which had loading below 0.3 were excluded. Thus, the final version of the questionnaire had 39 items. The outcome of factor analysis reveal loading under four factors: interest/enjoyment, perceived competence, value/importance, and effort (see Appendix 2).

The students were asked to complete the questionnaire without mentioning their names, as it is believed that the anonymous feature of the questionnaire might encourage students to give more accurate and honest responses.

\subsubsection{Data collection}

Data collection was performed in the second and third steps of the present study. In the second step, the questionnaire was marked by each student at the beginning of the term. In the third step, the language learners marked the questionnaire at the end of the term. The total score of each questionnaire was calculated.

\section{Data analysis and discussion}

To find out the impact of self-assessment on motivation, the scores in the questionnaire were analyzed. The particular analysis used was paired sample t-test. Within both experimental and control groups, this test was run to check the probable effect of self- assessment on promoting learners' motivation. Table 2 illustrates the results for the experimental group. The results show a significant difference between the scores of pre- motivation questionnaire $(\mathrm{M}=140.33, \mathrm{SD}=17.4)$ and post- motivation questionnaire $(\mathrm{M}=160.63, \mathrm{SD}=14.87), \mathrm{t}(29)=-5.016$, $\mathrm{p}<.01$. Table 3 shows the results of running paired sample t-test for the control group.

As the table illustrates there is no significant difference between the scores of pre- motivation questionnaire $(\mathrm{M}=143.93, \mathrm{SD}=15.64)$ and post- motivation questionnaire $(\mathrm{M}=145.56, \mathrm{SD}=14.94), \mathrm{t}(29)=-.388, \mathrm{p}>.05$. It should be noted that the mean difference between the scores of the motivation questionnaire in the experimental and the control group was not significant at the beginning of the term due to the independent sample t-test. Table 4 shows the results. As the table indicates, the difference between the scores of the pre- motivation questionnaire in experimental group ( $\mathrm{M}=140.13, \mathrm{SD}=17.04)$ is not significantly different from the control group $(\mathrm{M}=143.93$, $\mathrm{SD}=15.64), \mathrm{t}(58)=-.900, \mathrm{p}>.05$. The magnitude of the difference in the means of these two groups was also very small ( eta squared $=0.005$ ).

Based on the results in Tables 2, 3, and 4, we can realize that journal writing as a self- assessment technique was effective in enhancing learners' motivation, specifically intrinsic motivation. Apart from the results of the motivation questionnaire, observing the students through the term showed that they had gained more confidence in their writing. In their journal, some of the students wrote:

(e.g., S1=Student number 1)

S 2: Today is last session. I am thinking of myself. I wonder if this class improve my writing or not. I think yes. When I look at my writing paper which we wrote every session, I can see my progress.

S 4: I want to thank you to help me to have self-confidence. Now I can write, right or wrong...

S 25: We have to write our journals. All the students open their notebooks and take their pens to write it. I myself write like other students. Maybe it is the first time that I am writing alone with no help.

S 9: Our writing class was a good motivation to start a good and energetic week. I always enjoy in this class.

S 18: I was absent last session. I was sorry for missing my class. I myself couldn't believe that I had such a strong desire to go to my writing class. I never forgot the first session. I just hated writing.

S 12: I know when I habit to write dairy in English it helps me to write very well.

S 21: At first I was afraid of writing, but now I have self-confidence.

S 7: Journal writing helps us to say our idea about class, course and whatever we like tension.

without feeling any 


\section{S 20: Journal writing was great because I can say to you what I cannot say orally.}

S 5: In the first session I wrote three lines but at the end of the term I wrote one page.

S 14: I never look at my watch in writing class!

Even the days the students were absent, they wrote their journals at home without being required to do so:

S 8: This session I am absent again. I catch a bad cold. I am in bad mood and I couldn't even speak. I' $m$ really sorry teacher.

S 11: I have a frog in my throat and I can't speak a word! So I gotta stay home and rest.

S 23: How bad! I really miss the class! Sneeze!....

All these show their increased interest, and consequently their motivation in writing. The result of this study is in line with a number of studies mentioned above that emphasize the role of self- assessment in promoting learners motivation (e.g., Ellis, 1994; Peirce, Swain, \& Hart, 1993; Brown, 2004; Mirhosseini, 2009). It seems that self-assessment may best serve as a complementary instrument to traditional assessment.

Finally, it should be mentioned that although there was no measure to examine the extend to which students have gained self- confidence, the amount of their journal writing could be an evidence in this regard. The students who only wrote very few lines in their journals at the beginning of the course, could complete a paragraph or more at the end. The learners showed that journal writing could improve their self- confidence as well.

\section{Conclusion}

The techniques of self-assessment and evaluation play important part in evaluating the effectiveness of individual learning, enhancing their motivation, and training learners for life long learning. Learners need to assess their progress and accomplishments in order to plan their future learning. It seems that self-assessment can not only raise the students' self-awareness about their meta-cognitive conditions, but also can promote their motivation. As the results of the study also revealed, journal writing, as a self- assessment technique, can be used as an effective tool for enhancing learners' intrinsic motivation and improving their self- confidence. This is absolutely important in our Iranian EFL context which highly depends on the role of the teacher in teaching and evaluation. It is generally assumed that in teacher-centered classes, despite being knowledgeable, students lack self- confidence. Journal writing, as shown in this study, can be used as an effective tool in helping the learners 'think aloud' on paper, and get involved in the process of their own learning.

However, because self-assessment in general is performed through complex cognitive processes which are affected by many uncontrollable factors, there still remains much disagreement in the discussion regarding the effective use of self- assessment. Despite a number of difficulties in appropriately implementing self-assessment, the ways in which we resolve these issues will certainly provide valuable insights into the nature of language teaching, learning, and assessment. When these challenges are met, it is hoped that language institutions and classroom teachers will consider the potential of self-assessment as both a valid and reliable supplement to traditional assessment, and its effective role in promoting self-directed learning.

\section{References}

Allwright, D. (1983). Classroom- Centered Research on Language Teaching and Learning: A Breif Historical Overview. TESOL Quarterly, 17(2), 191-204

Atkinson, D. (2003). Writing in the Post-Process Era: Introduction. Journal of Second Language Writing, 12(1), $3-15$.

Black, P. \& William, D. (1998).Assessment and Classroom Learning. Assessment in Education, 5 (1), 7-74.

Brown, H. D. (2004). Language Assessment: Principles and Classroom Practices. New York: Longman.

Clement, R., Dornyei, Z., \& Noels, K. A. (1994). Motivation, Self-confidence, and Group Cohesion in the Foreign Language Classroom. Language Learning, 44, 417-448.

Deci, E. L., \& Rayan, R. M. (1985). Intrinsic Motivation and Self-determination in Human Behavior. New York: Plenum

Dörnyei, Z. (2000). Motivation' \& 'Motivation Theories. In M. Byram (Ed.) Routledge Encyclopedia of Language Teaching and Learning. London: Routledge, pp. 425-435.

Dornyei, Z. (2009). The L2 Motivational Self System. In Z. Dornyei \& E. Ushioda (Eds.) Motivation, Language Identity and the L2 Self. Clevedon: Multilingual Matters. 
Ellis, R. (1994). The Study of Second Language Acquisition. Oxford: Oxford University Press.

Guilloteaux, M. J. \& Dornyei, Z. (2008). Motivating Language Learners: A Classroom- oriented Investigation of the Effects of Motivational Strategies on Student Motivation. TESOL Quarterly, 42(1), 55-77.

Genesee, F. \& J. Upshur (1996). Classroom-based Evaluation in Second Language Education. Cambridge: Cambridge University Press.

Hayland, K. (2003). Genre-based Pedagogies: A Social Response to Process. Journal of Second Language Writing, 12(1), 17-29.

Kavaliauskiene, G. (2004). Quality Assessment in Teaching English for Specific Purposes. ESP World. Available: http://esp-world.info/Articles

Kerka, S. (1996). Journal Writing and Adult Learning. ERIC Digest, 174.

Liang, J. (2006). Overview of Self-assessment in the Second Language Writing Classroom. Paper presented at the 2006 TESOL Convention, Tampa, Florida. Available: http://secondlanguage writing.com/documents/overview.doc.

Marefat, F. (2002). The Impact of Diary Analysis on Teaching/Learning Writing. RELC Journal, 33, 101-121. Avalable: http://www.sagepublications.com

Matsuno, S. (2009). Self-, Peer-, and Teacher- assessments in Japanese University EFL Writing Classrooms. Language Testing, 29(1), 75-100.

McMillan, J. H. \& Hearn, J. (2008). Student Self-assessment: The Key to Stronger Student Motivation and Higher Achievement. Educational Horizons, 87(1), 40-49

Mirhosseini, S. A. (2009). For our Learn of English: Dialogue Journal Writing in EFL Education. PROSPECT, 24(1), 40-47.

Mori, S. (2002). Redefining Motivation to Read in a Foreign Language. Reading in a Foreign Language, 14(2). Available: http://njlrc.hawaii.edu/rfl/October2007/mori/mori.html

Noels, K. A., Pelletier, L.G., Clement, R. \& Vallerand, R.J. (2000). Why are you learning a second language? Motivational Orientations and Self-determination Theory. Language Learning, 50(1), 57-85.

Orsmond, P., Merry, S. \& Reiling, K. (1997). A Study in Self-assessment: Tutor and Students' Perceptions of Performance Criteria. Assessment \& Evaluation in Higher Education, 22, 357-369

Oscarson, M. (1989). Self-assessment of Language Proficiency: Rationale and Applications. Language Testing, 6(1), 1-13.

Nunan, D. (1999). Second language teaching and learning. Boston: Heinle \& Heinle.

Pae, T. (2008). Second Language Orientation and Self-Determination Theory: A Structural Analysis of the Factors Affecting Second Language Achievement. Journal of Language \& Social Psychology, 27(1), 5-27.

Peirce, B. N., Swain, M., \& Hart, D. (1993). Self-assessment, French Immersion, and Locus of Control. Applied Linguistics, 14(1), 25-42.

Porter, A. P., Goldstein, L. M., Leatherman, J., \& Conrad, S. (1990). An Ongoing Dialogue: Learning Logs for Teacher Preparation. In J. Richards \& D. Nunan (Eds.). Second Language Teacher Education. Cambrideg: Cambrideg University Press.

Schneider, P. (1994). The Writer as an Artist. Los Angeles: Lowell House.

Sullivan, K. \& Hall, C. (1997). Introducing Students to Self-assessment. Assessment \& Evaluation in Higher Education, 22 (3), 1-15. Available: http://web.ebscohost.com.ezproxy.ub.gu.se/

Taras, M. (2001). The Use of Tutor Feedback and Student Self-assessment in Summative Assessment Tasks: Towards Transparency for Students and for Tutors. Assessment \& Evaluation in Higher Education, 26(6), 606-614.

Truesdell, t. (2008). Problems with Bruffee: Post-process Theory and Writing Center Opposition. Available: http://projects.uwc.utexas.edu/praxis/?q=node/197

Walker, S. E. (2006). Journal Writing as a Teaching Technique to Promote Reflection. Journal of Athletic Training, 41(2), 216-221. 
Wang, H., \& Wang, Y. (2007). The Addition of an Affect Test and Self-assessment into ESL Writing Assessment: Process and Effect. Asian EFL Journal, 20.

Table 1. Reliability Statistics

\begin{tabular}{|c|c|c|}
\hline Cronbach's Alpha & Cronbach's Alpha Based on Standardized Items & N of Items \\
\hline .830 & .841 & 50 \\
\hline
\end{tabular}

The reliability of the questionnaire

Table 2. Paired Samples Test

\begin{tabular}{|c|c|c|c|c|c|c|c|c|c|}
\hline & & \multicolumn{8}{|c|}{ Paired Differences } \\
\hline & & \multirow{2}{*}{ Mean } & \multirow{2}{*}{$\begin{array}{c}\text { Std. } \\
\text { Deviation }\end{array}$} & \multirow{2}{*}{$\begin{array}{l}\text { Std. Error } \\
\text { Mean }\end{array}$} & \multicolumn{2}{|c|}{$\begin{array}{c}95 \% \text { Confidence Interval of } \\
\text { the Difference }\end{array}$} & \multirow[t]{2}{*}{$\mathrm{t}$} & \multirow{2}{*}{$\mathrm{df}$} & \multirow{2}{*}{ Sig. (2-tailed) } \\
\hline & & & & & Lower & Upper & & & \\
\hline Pair 1 & $\begin{array}{l}\text { motivation questionnaire } 1 \\
\text { motivation questionnaire } 2\end{array}$ & -20.500 & 22.38341 & 4.08663 & -28.85810 & -12.14190 & -5.016 & 29 & .000 \\
\hline
\end{tabular}

Paired t-test for the experimental group

Table 3. Paired Samples Test

\begin{tabular}{|c|c|c|c|c|c|c|c|c|c|}
\hline & & \multicolumn{8}{|c|}{ Paired Differences } \\
\hline & & \multirow[t]{2}{*}{ Mean } & \multirow{2}{*}{$\begin{array}{c}\text { Std. } \\
\text { Deviation }\end{array}$} & \multirow{2}{*}{$\begin{array}{l}\text { Std. Error } \\
\text { Mean }\end{array}$} & \multicolumn{2}{|c|}{$\begin{array}{l}95 \% \text { Confidence Interval of } \\
\text { the Difference }\end{array}$} & \multirow[t]{2}{*}{$\mathrm{T}$} & \multirow[t]{2}{*}{$\mathrm{df}$} & \multirow{2}{*}{$\begin{array}{c}\text { Sig } \\
\text {. (2-tailed) }\end{array}$} \\
\hline & & & & & Lower & Upper & & & \\
\hline Pair 1 & $\begin{array}{l}\text { motivation questionnaire } 1 \\
\text { motivation questionnaire } 2\end{array}$ & -1.633 & 23.04042 & 4.20659 & -10.23677 & 6.97010 & -.388 & 29 & .701 \\
\hline
\end{tabular}

Paired t-test for the control group

Table 4. Independent Samples Test

\begin{tabular}{|cc|c|c|c|c|c|c|c|c|}
\hline & \multicolumn{2}{|c|}{$\begin{array}{c}\text { Levene's Test for } \\
\text { Equality of } \\
\text { Variances }\end{array}$} & \multicolumn{2}{|c|}{ t-test for Equality of Means } \\
\cline { 2 - 9 } & $\mathrm{F}$ & Sig. & $\mathrm{t}$ & $\mathrm{df}$ & $\begin{array}{c}\text { Sig. } \\
(2 \text {-tailed })\end{array}$ & $\begin{array}{c}\text { Mean } \\
\text { Difference }\end{array}$ & $\begin{array}{c}\text { Std. Error } \\
\text { Difference }\end{array}$ & $\begin{array}{c}95 \% \text { Confidence Interval } \\
\text { of the Difference }\end{array}$ \\
\hline $\begin{array}{cc}\text { Equal variances } \\
\text { assumed } \\
\text { questionnaire 1 } \\
\text { Equal variances } \\
\text { not assumed }\end{array}$ & .115 & .736 & -.900 & 58 & .372 & -3.80000 & 4.22436 & -12.2560 & 4.65597 \\
\hline
\end{tabular}

Independent samples t-test for both experimental and control groups

\section{Appendix 1}

Please indicate how much you agree or disagree with the following statements by circling the number which best fits you.

\section{1}

strongly disagree
2 disagree
3 neutral
4 agree
5 strongly agree

1. I enjoy learning English.

2. I am the kind of person who makes great efforts to learn English.

3. I believe writing could be of some value to me.

4. Learning English is hard work, but I enjoy hard work.

5. In my opinion, I know enough English to be able to write comfortably. 
6. I can honestly say that I am really doing my best to learn writing.

12345

7. I find writing classes of no use.

8. I get pleasure from reading what I have written in English.

12345

9. I always look forward to my writing classes.

12345

12345

10. I think I do pretty well at writing, compared to other students.

11. I think I am wasting my time in writing classes.

12345

12. I like to write in English for the pleasure I experience when I

discover new ways to express myself.

12345

13. I do not think that writing is an important subject.

14. I am sure I have a good ability to learn English.

15. I put a lot of effort into writing.

12345

16. I would describe writing classes as very interesting.

12345

17. I usually do not volunteer to read my composition in writing classes.

12345

18. I believe writing is an important skill.

12345

19. I wish we had more writing classes.

12345

20. I am satisfied with my writing activities.

21. What I do in writing classes is useful for me.

22. I enjoy hard work.

23. Writing activities do not hold my attention at all.

12345

24. I cannot do very well in writing activities.

12345

26. Studying English is important because it is used everywhere.

27. I think I would take writing classes even if they weren't compulsory.

28. In my writing classes, I seldom do more than what is necessary.

29. I worry that the other students will laugh at me when I read my writing.

30. While I am doing a writing assignment, I think about how much I enjoy it.

31 . To be honest, most of the time I do not do my writing assignments.

32. I would rather spend my time on subjects other than English.

33. It is extremely important for me to learn English.

34. I never attend my writing classes without doing my homework.

35. Learning English is one of the most important aspects in my life.

36. If I make more effort, I am sure I will be able to master English.

37. I always feel that my classmates write in English better than I do.

38. Learning English is an important part of education.

39. I easily give up goals which seem hard to reach.

\section{Appendix 2}

Thank you for your cooperation

\section{The Intrinsic Motivation Questionnaire- Factor loading}

Factor 1: interest/enjoyment, 12 items, Chronbach Alpha $=0.82$

1. I enjoy learning English.

4. Learning English is hard work, but I enjoy hard work.

8. I get pleasure from reading what I have written in English.

9. I always look forward to my writing classes.

12. I like to write in English for the pleasure I experience when I discover new ways to express myself.

16. I would describe writing classes as very interesting.

19. I wish we had more writing classes.

23. Writing activities do not hold my attention at all.

25. If my teacher wants someone to do an extra writing assignment, I will certainly volunteer.

27. I think I would take writing classes even if they weren't compulsory.

30. While I am doing a writing assignment, I think about how much I enjoy it.

32. I would rather spend my time on subjects other than English.

Factor 2: perceived competence, 8 items, Chronbach Alpha $=0.83$

5. In my opinion, I know enough English to be able to write comfortably.

10. I think I do pretty well at writing, compared to other students.

14. I am sure I have a good ability to learn English.

17. I usually do not volunteer to read my composition in writing classes.

20. I am satisfied with my writing activities. 
24. I cannot do very well in writing activities.

29. I worry that the other students will laugh at me when I read my writing.

37. I always feel that my classmates write in English better than I do.

Factor 3: value/importance, 10 items, Chronbach Alpha $=0.78$

3. I believe writing could be of some value to me.

7. I find writing classes of no use.

11. I think I am wasting my time in writing classes.

13. I do not think that writing is an important subject.

18. I believe writing is an important skill.

21. What I do in writing classes is useful for me.

26. Studying English is important because it is used everywhere.

33. It is extremely important for me to learn English.

35. Learning English is one of the most important aspects in my life.

38. Learning English is an important part of education.

Factor 4: effort, 9 items Chronbach Alpha $=0.82$

2. I am the kind of person who makes great efforts to learn English.

6 . I can honestly say that I am really doing my best to learn writing.

15. I put a lot of effort into writing.

22. I enjoy hard work.

28. In my writing classes, I seldom do more than what is necessary.

31 . To be honest, most of the time I do not do my writing assignments.

34. I never attend my writing classes without doing my homework.

36. If I make more effort, I am sure I will be able to master English.

39. I easily give up goals which seem hard to reach. 